\title{
Die Ziedţffpredtung
}

Sex

\section{Qbexlandesgexichfe auf dem (Gebiefe des Bivilredhts.}

\author{
Gerauşgegeben bon

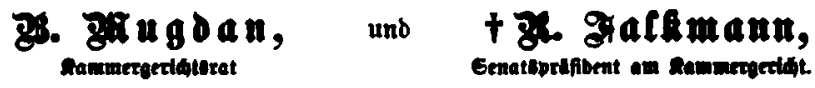

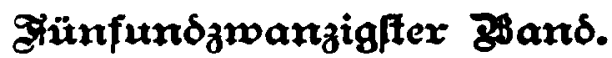 \\ (J̧aלrgang 1912, zweiteß \$albjabr.)
}

sciptis,

Berlag bon Beit \& Comp 